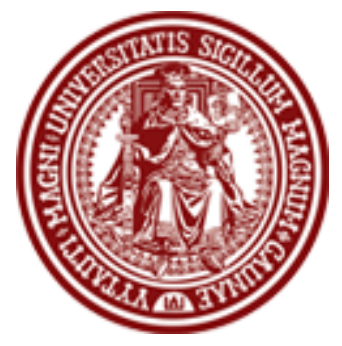

BALTIC JOURNAL OF LAW \& POLITICS

VOLUME 6, NUMBER 1 (2013)

ISSN 2029-0454

http://www.degruyter.com/view/j/bjlp

Cit.: Baltic Journal of Law \& Politics 6:1 (2013): 27-44

DOI: $10.2478 / \mathrm{bjlp}-2013-0002$

\title{
DIRECT DEMOCRACY AND ITS INDIRECT NEUTRALIZATION IN POLITICAL SYSTEMS: \\ LEARNING FROM THE CASE OF ESTONIA
}

\author{
Ero Liivik \\ Ph.D. Candidate \\ Faculty of Social Sciences and Education, University of Tartu (Estonia) \\ Estonian Academy of Security Sciences (Tallinn) \\ Contact information \\ Address: Kase Street 61, 12012 Tallinn, Estonia \\ Phone: +372 5064330 \\ E-mail address: eliivik@yahoo.com
}

Received: January 8, 2013; reviews: 2; accepted: May 12, 2013.

\section{ABSTRACT}

The Estonian parliament is the only institution in the country that may call a referendum, i.e. the parliament itself can formulate the crucial question and put it forward for people to vote. The constitution, though, lacks the institution to harness the people's initiative, giving citizens an opportunity to put some questions or draft acts to vote by themselves. A large group of MP's submitted a draft of an amendment to the constitution which would add people's initiative, with 25,000 signatures gathered, enabling them to put a draft act or question for vote. This draft act was in legislative proceedings on two separate occasions but failed to be completed and take effect within those eight years. In the parliamentary debates we could see a strong "clash of discourses". On the one side, the proponents of direct democracy stressed different aspects of "alienation of power"; unfortunately the parliament as a representative body maintained the sole monopoly to act, while the parliamentary elections have been media-manipulated by certain interest groups. Alternately, other speakers on the contrarian-side shared the view according to which direct democracy is unnecessary, even risky, populist means to cope with the strain of 
governance. Curiously, the deliberations in the parliament did not change anything; previously existing relationships of power were maintained.

\section{KEYWORDS}

Direct democracy, political discourses, parliament, democracy 


\section{INTRODUCTION: REFERENDUM AS A POLITICAL TOOL IN MODERN DEMOCRACIES}

Methods of direct democracy have emerged lately into a visible place alongside representative democracy and national parliaments: for example, referenda were conducted in countries which joined the European Union. Direct democracy plays a minor role also in the European Union's reform process; the most recent case was voting over the Treaty of Lisbon in Ireland 2008 and 2009. The situation of referenda seemingly always brings controversy; for example, the extension of the European Union was practically stopped when the Netherlands and France denied it through referendums in 2005. Comparatively, the world-famous example is Switzerland, where direct democracy has an organic importance in the political process: it has often been used on the state, county, and local government levels. But what is the main difference between direct and representative democracy? Canadian professor of political science, Lawrence Le Duc explains that in the case of direct democracy, citizens vote directly over a project of law or a political decision; a referendum may be initiated either by the government or some other public body, e.g. the President of the state, but a citizen-initiated referendum (popular initiative) is started only by citizens themselves. ${ }^{1}$ International scholars Uwe Serdült and Yanina Welp showed that in the case of popular initiatives there exists a requirement to collect a certain number of signatures, for example 25000 , after which the bill is ready to submit for voting. ${ }^{2}$ Direct democracy also differs from surveys or polls, because the result of the vote is binding for all state authorities. Direct democracy is not replacing parliaments-it is more like a symbiosis or healthy supplementation. David E. Butler and Austin Ranney have explained that the most important reason here is the need to increase the legitimacy of political decisions: because people themselves want referendums to be arranged, they regard the outcome as an authentic expression of their will. ${ }^{3}$ Political scientist Maija Setälä has expressed a point of view that the use of direct democracy will also thoroughly foster a country's political culture. ${ }^{4}$ However, despite these positive aspects, which can be attributed to the referenda, there has been no renaissance in activity: parliaments and governments are still the main driving force behind political decisions. Some political elites believe that direct democracy is a very bad

1 Lawrence LeDuc, The Politics of Direct Democracy. Referendums in Global Perspective (Toronto: University of Toronto Press, 2003).

2 Uwe Serdült and Yanina Welp, "Direct Democracy Upside Down," Taiwan Journal of Democracy 8:1 (2012).

3 David Butler and Austin Ranney, Referendums Around the World: The Growing Use of Direct Democracy (Washington: The American Enterprise Institute Press, 1994).

${ }^{4}$ Maija Setälä, "On the problems of responsibility and accountability in referendums," European Journal of Political Research 45 (2006). 
example of the detrimental effects of populism and manipulation and should not be allowed with much frequency, or at least this is what is best for the people. One such country is Estonia: even though the constitution of Estonia allows referendums, there has been only one in the last twenty years.

The goal of this article is to analyse the reasons that direct democracy in Estonia has been so minimally applied. Much has been written on applying direct democracy in the past decade. However, dealing with the factors that have obstructed direct democracy from emerging as a decision-making tool along with representative democracy and parliamentarism have not drawn much attention at all. To employ a referendum it generally is necessary to ground it by a decision of the parliament or government, thus the views of the political elite towards direct democracy are of crucial significance. I contend that it is most suitable to use qualitative methods for them, and this article applies the method of discourse analysis in relation to debates on legalising direct democracy in the parliament of Estonia. This article aims to highlight why politicians and parties in power in the parliament hold mostly a negative opinion of direct democracy. The concluding part of this article analyses discourses apparent in parliamentary discussions to help best bring out the prevailing attitudes. Notably, the present article will not focus on the referendum situation but instead attempts to explain the "dragging processes" and why authorities never reach the point of holding referendums, despite that national legislation provides the opportunity to hold them. The article also concentrates on the deliberation phases of the draft legislation on legitimising direct democracy in the Estonian parliament, observing how the political elite groups express their views on direct democracy.

\section{THE CASE IN QUESTION: PARLAMENT AND DIRECT DEMOCRACY IN}

\section{ESTONIA}

On the whole the study of referendums or direct democracy has been largely conducted according to the pattern "better - worse" than representative democracy (or making political decisions in the parliament). Various researchers have tried to understand why referendums are better than the parliament (I will call them "activists"), others proceed from the opposite angle, trying to prove that direct democracy is an inadequate or poor method for making decisions. The secondary literature largely sticks to normative theoretical discussions. The aforementioned should not, however, be understood as entirely incorrect or be taken to be a subject that cannot be treated in that way. Any particular democratic system is unique to its given country - yet it operates by rules shared by many 
and develops its operating practices that generalize from single case to general notion of "democratic system". At the sociological level, any referendum provides a unique circumstance. Within a society, the proportion of any direct democracy is also unique depending on the history of the country, political organization(s), activities of the parties in the political landscape, legislation, etc.; therefore the referendum is a unique, individual case which demands that the uniqueness of the referendum situation to be studied, in order to find out the fundamental circumstances that have developed events in one direction or another. Estonia is a Baltic country belonging to the European Union, and twenty years ago it freed itself from the Soviet occupation. After seceding from the Soviet Union Estonia started to build up a democratic political statehood with a 101-member parliament as its political centrepiece, elected for four years. Members in the parliament are politicians elected according to lists representing parties. Alongside representative democracy the constitution establishes an opportunity for direct democracy: a referendum can be held. However, only once within the twenty years of independence has a referendum been carried out, which happened to be in connection with the matter of becoming a member country of the European Union (it should be noted that there were political forces in Estonia that did not want the referendum to be conducted). In contrast to other the Baltic countries (Latvia, Lithuania), Estonia's referendums play a minuscule role in the political processes of the country. Latvia and Lithuania stand out clearly in comparison with Estonia as quite active proponents of direct democracy. Over the years (1992-2011) there have been 14 people's initiatives in Lithuania and 6 in Latvia and also 9 referendums in Lithuania and 7 in Latvia, according to authors of Estonian Human Development Report 2011; the constitutions of Latvia and Lithuania legalise all four types of referendums, in Estonia only the parliament may initiate the referendum. ${ }^{5}$ In principle this situation reflects statements on reasons for holding or not holding referendums occurring in political literature. Over the years, there has been consolidation of the political system in Estonia: in the 1990s there were around 30 active parties in Estonia; after the election in 2011, four main parties were represented.

The Estonian parliament is the only institution that provides the referendum, i.e. the parliament itself can formulate the crucial question and put it forward for people to vote. The constitution, though, lacks the institution of the people's initiative giving citizens an opportunity to put some questions or draft acts to vote by themselves through gathering a certain amount of signatures. It is the more

\footnotetext{
${ }^{5}$ Estonian Human Development Report 2011, Baltic Way(s) of Human Development: Twenty Years On (Tallinn: Eesti Koostöö Kogu, 2011), p. 155 // http://kogu.ee/public/eia2011/eia_eng_2011.pdf (accessed November 23, 2012).
} 
noteworthy that a large group of delegates submitted a draft of an amendment to the constitution which would add people's initiative. This point warrants closer analysis. The referred draft act ("Draft Act of the Amendment to the Constitution of the Republic of Estonia on Legalising the People's Initiative") was in legislative proceedings of two compositions (in 2003-2007 and 2007-2011) but failed to be completed and take effect within those eight years (!) (Draft Act 109 SE). Though the draft act repeatedly was dropped off the proceedings (see Table 1 ) and thus obtained a new number, the principle of the people's initiative remained unchanged. The text of the law was extremely laconic, stipulating the popular initiative be included in the constitution, provided that the electorate consisting of at least 25,000 citizens have right to put an issue to a vote by way of the popular initiative, whereas the national budget, taxes, country's financial obligations, ratification and denunciation of international treaties, declaration of a state of emergency and ending it, and issues of national defence cannot be put to popular vote.

In 2003 a project called Remote Internet Voting was launched in Estonia aimed at ID chip card owners who vote at home, making use of their PCs and the Internet. The first national elections with I-voting were held in October 2005 for local governments and the number of 'I-voters' has grown year-to-year. I-voting is a legalised form of voting for the referendum, but the last referendum in Estonia was held in 2003, before legalising I-voting. However, it may be used in future referenda. Currently there are no comparative statistics to estimate the impact on I-voting either increasing the turnover of active voting in the referendum or, vice versa, reducing it. ${ }^{6}$

Table 1. Legalizing proceedings of the popular initiative in the Riigikogu

\begin{tabular}{|c|c|}
\hline Initiation of the draft and its number & Results of the vote \\
\hline $\begin{array}{l}7 \text { August } 2003 \text { - draft legislation for the } \\
\text { amendment to the constitution of the Republic } \\
\text { of Estonia, initiated by } 25 \text { members of the } \\
\text { Riigikogu to legalise the popular initiative ( } 109 \\
\text { SE). }\end{array}$ & $\begin{array}{l}7 \text { October } 2003 \text { - on the proposal of the } \\
\text { faction of the Estonian Reform Party it } \\
\text { was denied in the first reading. } 47 \text { votes } \\
\text { for and } 33 \text { against by the members of } \\
\text { the Riigikogu, nobody abstained. }\end{array}$ \\
\hline $\begin{array}{l}20 \text { January } 2005 \text { - draft legislation for the } \\
\text { amendment to the constitution of the Republic } \\
\text { of Estonia, initiated by } 21 \text { members of the } \\
\text { Riigikogu to legalise the popular initiative ( } 562\end{array}$ & $\begin{array}{l}22 \text { March } 2005 \text { - } 38 \text { members of the } \\
\text { Riigikogu voted against and } 17 \text { for } \\
\text { denying the draft legislation. }\end{array}$ \\
\hline
\end{tabular}

6 Ülle Madise and Priit Vinkel, "Constitutionality of Remote Internet Voting: The Estonian perspective," Juridica International VXIII (2011). 


\begin{tabular}{|c|c|}
\hline SE). & \\
\hline $\begin{array}{l}28 \text { September } 2006 \text { - draft legislation for the } \\
\text { amendment to the constitution of the Republic } \\
\text { of Estonia, initiated by } 35 \text { members of the } \\
\text { Riigikogu to enable the popular initiative ( } 982 \\
\text { SE). }\end{array}$ & $\begin{array}{l}24 \text { October } 2006-\text { proposal by the } \\
\text { Constitutional Committee of the Riigikogu } \\
\text { to withdraw the draft legislation. } 33 \\
\text { members of the Riigikogu voted for the } \\
\text { proposal, } 36 \text { against, no abstainers. The } \\
\text { proposal found no support. }\end{array}$ \\
\hline $\begin{array}{l}28 \text { February } 2008 \text { - draft legislation for the } \\
\text { amendment to the constitution of the Republic } \\
\text { of Estonia, initiated by } 25 \text { members of the } \\
\text { Riigikogu to legalise the popular initiative } \\
(210 \mathrm{SE}) \text {. }\end{array}$ & $\begin{array}{l}24 \text { April } 2008 \text { - the first reading of the } \\
\text { draft legislation was completed, it was } \\
\text { decided to be passed to the second } \\
\text { reading and time was set for a motion to } \\
\text { amend by } 4.45 \text { pm, } 23 \text { May } 2008 \text {. }\end{array}$ \\
\hline
\end{tabular}

Note: compiled by the author on the basis of the Riigikogu in information found at: www.riigikogu.ee.

\section{DISCOURSES ON DIRECT DEMOCRACY IN DISCUSSIONS OF THE}

\section{RIIGIKOGU}

\subsection{DISCOURSES FAVOURING DIRECT DEMOCRACY}

In the parliament it is typical to express different views and oppose some views to others. Political discourse being shaped during parliamentary deliberations plays a crucial role-it determines how the public will accept what remains beyond these channels; winning arguments in the parliament can determine a direction for the entire society. Professionals acting in the political battlefield also settle the result of direct democratic debate between them and it will later be boosted by media channels; that is how hegemony is established. Pierre Bourdieu has precisely pointed out that "the boundary between what is politically sayable or unsayable, thinkable or unthinkable, for a class of non-professionals is determined by the relations between the expressive interests of that class and the capacity to express these interests, a capacity which is secured by its position in the relations of cultural and thus political production". ${ }^{7}$ In actual parliamentary practice principles of deliberative democracy are difficult to apply, because different political forces make use of resources distributed disproportionally. As voting becomes decisive, a certain mechanism becomes the basis of political decisions.

The present study makes use of stenographic records and minutes of the parliament, thus penetrating into the realm of the mind and imagination of political figures. What do stenographic records talk about? In parliament sittings delegates

\footnotetext{
${ }^{7}$ Pierre Bourdieu, Language and Symbolic Power (Cambridge: Harvard University Press, 1992), p. 172.
} 
take the floor to argue with one another, express supporting or opposing views for or against the law, attempt to "outplay" political opponents, etc. The political parties maintain interest in expanding their political capital. Though the parliament history in Estonia is relatively short (twenty years) and political culture, including the culture of debating in parliament, is not very elaborate, all debates are documented; stenographic records are made and made public via the site www.riigikogu.ee, i.e. available to researchers, which in fact provided the necessary material for writing this article. It is essential to keep in mind that the parliament in Estonia works a lot with drafts in respective committees and passes all rough and hard work, so that in the "great hall" of the parliament in the presence of all 101 members only voting is conducted. Before voting a content-relevant discussion may or may not take place; as will be seen in some cases discussions were active pertaining to the content, in other cases they were only formal containing a couple of interrogative sentences. I conducted qualitative research to find out reasons why direct democracy at that time was not held in high (and popular) opinion, and dealt with discourse on direct democracy as it emerged and developed during deliberations on the popular initiative in the Riigikogu within 2003-2008. Discourse analysis enables an investigation into how much power and what sort of fights for power have an impact on practical language usage and ideologies of an institution in addition to relationships of power - in recent years scholars of politics have demonstrated an increasing interest in the interrelation between language and politics. Within the variety of methods and approaches of discourse analysis, scholars have taken special interest in critical discourse analysis (CDA). ${ }^{8}$ In the course of research I analysed shorthand notes of sessions with draft legislation for legalising the popular initiative on the agenda of the Riigikogu.

In the deliberation process the most varied discourses in favour of and opposite to direct democracy were expressed. Within the entire period under study major points supporting the popular initiative were given by the Centre Party's faction members, seconded by members of the Estonian People's Party and the Estonian Greens. Despite differences in the discourse of party category basis, differentiation occurred on the coalition-opposition axis, i.e. representatives in opposition employed more favourable discourses to the popular initiative. Representatives of right-wing parties predominantly conveyed discourses contrasting direct democracy. A catalogue of discourses favouring the popular initiative and direct democracy from shorthand notes, selected by the author as

\footnotetext{
${ }^{8}$ Shaul R. Shenhav, Gideon Rahat, and Tamir Sheafer, "Testing the Language - Power Assumption of Critical Discourse Analysis: The Case of Israel's Legislative Discourse," Canadian Journal of Political Science / Revue canadienne de science politique 45:1 (2012).
} 
typical examples occurring in the majority of deliberations, is given in the form of a table below (Table 2).

Table 2. Discourses favouring direct democracy

1. Discourse of a social crisis: society is in moral and political crisis, and it is direct democracy in the form of the popular initiative that helps lead to changes.

2. Alienation discourse: there is a deep seated alienation of power in society, direct democracy will help lessen the gap; activity to vote declines in society as well as people's interest in taking part in politics; the popular initiative would return civil activity.

3. Discourse of civil society: the popular initiative will balance threats to the development of civil society; developing civil society must not be limited to delivering money only by the state, deliberations and debates are needed as well as dialogue between the peers.

4. Discourse opposing representative democracy: the parliament is encased in running its business, critical issues are discussed; the power is not open to or does not hold a dialogue with people but keeps to monologue. The legislator (i.e. the parliament) often obtains the so-called zero-risk-mentality, avoids discussing sensitive topics, focuses on retaining its position and keeping status quo.

5. Discourse of re-establishing confidence: legalising the popular initiative is a matter of trusting people which can lead us to the end of position warfare and to a much more dynamic society; initiation of this draft legislation will help bring a new and improved democracy to Estonia.

A study of the "order of discourse" is in order here. Several discourses and embedded discourses can be differentiated in the text: ${ }^{9}$

- Alienation discourse/Discourse opposing representative democracy/Discourse of re-establishing confidence:

How can the supreme power of state be vested in the people when the people have no right to initiate amendments to the constitution. The parliament elections as well as picking up, arranging, conducting people's voting does not actually depend on people at all; people have only the right to raise their hands. How can the people be with the supreme power when they are deprived of the right for legal initiation Now also about the objectives of the referred draft in short and summing up. First, for bringing before the public the very principal debate monitoring social development as a catalyst. Second, it would be worth mentioning returning the state law power function to people as direct bearers of

\footnotetext{
${ }^{9}$ Shorthand Notes of the Riigikogu, Reading of the "Draft Act of the Amendment to the Constitution of the Republic of Estonia on Legalising the People's Initiative" (October 7, 2003) // www.riigikogu.ee/?op=steno\&stcommand=stenogramm\&date $=1065510000 \#$ pk2000010017 (accessed November 15, 2012).
} 
the supreme state power. Third, expressed here simpler, for overcoming the gap between people and power. Fourth, for speeding up political socialization in Estonia (Evelyn Sepp, Central Party).

- Discourse of civil-society:

In fact it is not about considering wisdom, it is rather about balancing and opening up socio-political public sphere, in particular in the situation where Estonia has considerable shortcomings in the development of civic society, be it relative feebleness, frequently unwillingness to involve them in making decisions or lack of motivation inside the sector itself (Evelyn Sepp).

- Discourse of a social crisis/Alienation discourse/Discourse of re-establishing confidence:

It is important that people began to take interest in what they themselves were initiating and not that they in Toompea (i.e. the parliament) do something. Although draft bills may be exactly the same submitted here by delegates, parties, factions, the government. So there can be no doubt in the necessity of the people's initiative. Whether and when people's voting is necessary is a totally different issue. It is $100 \%$ sure that people must have an opportunity to call for people's voting by way of the people's initiative. In ten years democracy in Estonia has probably reached bigger manipulations in politics than the USA with its couple hundred years. So we should deal with possible or impossible manipulations within the framework of different laws, and not be afraid that one or the other law may call forth manipulations. There were manipulations during the elections and before and will be after the elections. The people's initiative may be the place for some issues to be made clear. When the elections produce a half-truth - and there are more of half-truths than one or two, and in more than one or two areas but in about ten or twenty - and a background where people feel at a loss, it helps reduce manipulation when the views of all people, all political parties, factions, government members and the government will be made clear as to dealing with particular questions, more important issues. I do admit that many questions have not been discussed over (Janno Reiljan, People's Union).

- Discourse of a social crisis/Alienation discourse/Discourse of re-establishing confidence:

Dear colleagues, recently the press and people here in the hall have more and more talked about people's alienation of power. Our opinion is that unfortunately such views are grounded. The draft under discussion will enable to reduce that alienation and provide people with an opportunity to participate in governing the state. As to much spoken manipulation and because of it certain interest groups were "placed" to power, in principle also parliamentary elections 
occur under the explicit influence of the media, through manipulation (Ain Seppik, Central Party).

Another example goes back to 2005 when at a deliberation Evelyn Sepp, representative of the initiators of the draft legislation, made a speech. Analysing the text (Shorthand Notes of the Riigikogu, 2005) reveals the following pattern: ${ }^{10}$

- Discourse of re-establishing confidence/Alienation discourse:

People's initiative in moral terms provides an opportunity to channel different political views and propositions before the most representative forum, which cannot be ensured by a formally proportional election system with yet a rather big distortion. It may turn necessary for various minority groups or underrepresented citizens to call forth obligatory and at the same time qualitative deliberation on crucial issues. Under certain circumstances this opportunity may be interpreted as a channel of managing social frustration. It gives an opportunity to learn how to conduct a dialogue with the public on issues that cannot draw the coalitions' interests, taking into account political trends, culture and may be logic, if you wish (Evelyn Sepp, Central Party).

\subsection{DISCOURSES OPPOSING DIRECT DEMOCRACY}

The variety of discourses opposing direct democracy is as diverse as the highlighted discourses. Several MPs hold it to be rather dangerous-certainly a demagogic and costly phenomenon, with decisions made this way being neither level-headed nor smart. In essence, introducing the popular initiative is considered of purposeless and in competition with the parliament. In short, direct democracy in terms of the popular initiative will be "a paved way to heaven accompanied with good intentions" (Table 3).

Table 3. Discourses opposing direct democracy

1. Discourse of a political tool: applying the popular initiative is "a permanent political election campaign", an activity paid with public money and proceeding from interests of one party or a small group.

2. Discourse of professional politics: there are no such issues which would need initiatives outside the parliament, which would not be revealed within the parliament; politics is a professional activity and now they want it to be shared with amateurs who would not even grasp what they sign for or against.

3. Populist discourse(s): this has to do with a populist initiative serving interests of

${ }^{10}$ Shorthand Notes of the Riigikogu, Reading of the "Draft Act of the Amendment to the Constitution of the Republic of Estonia on Legalising the People's Initiative" (March 22, 2005) // www.riigikogu.ee/?op=steno\&stcommand=stenogramm\&date $=1111478400 \#$ pk2000011837 (accessed November 15, 2012). 
such minority groups as homophobes or racists; the popular initiative will provide them with means of activity restricting rights of other minorities; if the popular initiative is not supported in the parliament and is voted down, it will cause conflicts in society and hostility towards parliamentary democracy.

4. Discourse of irresponsibility: the popular initiative may be made use of to paralyse work for parliamentary institutions or even block them; the popular initiative may, for example hamper selling out a state enterprise; the popular initiative will "give wrong answers" to important issues facing the state.

To begin with, consider a statement by MP Siim Kallas, speaking about direct democracy; we could distinguish here "main themes of opposing discourse", for example:

- Discourse of a political tool/ Discourse of irresponsibility: ${ }^{11}$

Applying the people's initiative seems to be a noble idea. The initiator of the draft spoke about the noble aspects of the idea at length. In reality those noble sides are but putative. It is all rhetoric which is widely used in the United States. In that sense it is interesting to study what California, USA, has experienced, and referred also by honourable Toomas Alatalu, where people's initiative and referendums have turned into everyday practice. Its eager champions, however, have noticed that people's decision-making has not extended. True, power has gone out of the legislative assembly but not to people; instead power is in the hands of public relations companies and lobby-groups with money. The skills and knowledge how to manipulate people has made the people of the United States of America seriously think about the future of democracy. It has been discovered with amazement that big money makes it much simpler to mobilise wide masses of people to protect their interests than to attempt and influence legislators. Extreme simplifying, playing on emotions and subconsciousness has had a much bigger role in influencing people than elected legislators. The most important thing here is that the examples of the USA and California have clearly shown that applying the people's initiative and referendums widely has not reduced the alienation of the citizens and the state; quite the opposite - the people have started taking such events making fool of themselves, with the mass media starring and the play at the forefront. A performer himself admitted, answering my question, that issues of too serious nature can not be proceeded by way of the people's initiative. Alas, how to explain it to people which question is serious and, which can and which cannot be proceeded by way of people's initiative. Therefore the Reform Party faction shall not support the continuation of the draft proceedings (Siim.Kallas, Reform Party).

${ }^{11}$ Shorthand Notes of the Riigikogu, supra note 9. 
It is very helpful to analyse the opinion(s) about the people's initiative represented by MP Lauri Vahtre, speaking about direct democracy on behalf of his colleagues: ${ }^{12}$

- Discourse of irresponsibility/Populist discourse:

I remind you that we here are representatives of people, not rulers or enemies of people, just representatives of people. And everyone of us is entitled to initiate a draft bill. Let us imagine now a situation where by way of the people's initiative we have to bring a draft bill to the parliament because no-one of 101 MPs wants it. Can you imagine any regulation, proposition, law or act which, on the one hand, serves as people's opinion without a single MP agreeing to let it be proceeded? I do not think such an opportunity is possible. We are people's representatives and we want to bring people's opinion here, we want to express our voter's will. Any draft bill or proposition reflecting people's explicit will is a proposition that MPs would storm. They would elbow each other aside to get the floor and pass over the draft. At present we obviously have to do with something else. In my opinion we have to do with a party request enabling the party's interest in representing it for people's opinion. Doing it in the parliament on behalf of their faction the state of being in minority would be too evident, revealing weak ground. Here we can count; if the proposition is represented by 25 out of a hundred it is a clear minority but when we gather 25,000 and say they represent people's opinion it would bring along confusion. There is a risk of destabilising the state; if such draft bills are brought to the parliament in succession, without revealing people's opinion but on behalf of people, the parliament will be obliged to exclude them from proceedings. Yet that creates a situation when the parliament may be accused of ignoring people's opinion and thus accumulate indefinite wrath against parliamentarianism and democracy which may one day explode to cause a burst of violation. Therefore I do not consider that draft bill good. Thank you! (Lauri Vahtre, Union of Pro Patria and Res Publica).

This final segment includes a speech made by MP Jürgen Ligi in which, standing in the Great Hall of the Parliament, he sets out to explain why he and the Estonian Reform Party did not favour the introduction of the popular initiative: ${ }^{13}$

- Discourse of irresponsibility/Discourse of professional politics:

We find ourselves at a breaking point; representative democracy does not work, the parliament operates as a filter letting good initiatives not pass through.

\footnotetext{
12 Shorthand Notes of the Riigikogu, Reading of the "Draft Act of the Amendment to the Constitution of the Republic of Estonia on Legalising the People's Initiative" (October 24, 2006) // www.riigikogu.ee/?op=steno\&stcommand=stenogramm\&date $=1161673200 \#$ pk2000013387 (accessed November 15, 2012).

${ }_{13}$ Shorthand Notes of the Riigikogu, Reading of the "Draft Act of the Amendment to the Constitution of the Republic of Estonia on Legalising the People's Initiative" (April 24, 2008) // www.riigikogu.ee/?op=steno\&stcommand=stenogramm\&date $=1209020700 \#$ pk2027 (accessed November 15, 2012).
} 
Politics as such smears therefore the parliament is not a desirable way of doing business. The parliament, in turn, does not trust people, thinking them to be too dim-witted. What she left unspoken is, in my opinion, why it is the filter; is it good for Estonia as a country, its society and its international reputation to discuss any issue in a formal way and here in the parliament. She did not interpret it why the referendums are prohibited in the fields of taxes, fiscal obligations of the state, international treaties, state defence and several others. Where is the logicality here that people in essence know sufficiently about all things, let alone a group of 25,000 ? I believe in the vitality of representative democracy. I do admit there is a lot of diffuse grudge focusing on trivia against direct democracy. But it should not be the reason for letting democracy downstream; it should be a stimulus for representative democracy to develop. I think we have been elected in a democratic way, we have been set to be, and this procedure is supporting the preparation, social thinking in the parliament above the average, which, at the same time, is our task. What we do here gives us information on deciding over social issues above the average and, summing it up, we are professionals.

- Populist discourse/Discourse of professional politics:

We may take responsibility; we have to consider various views. I state there are always very contradicting views represented in this hall. But summing it up, we produce an equilibrium, value some integrity and avoid extremists to emerge. Do we level too much? I hold that we rather are inclined to overestimate our popularity and underestimate rational arguments, for our own future directly depends on it. A disadvantage of politics lies in the tendency to prefer popularity rather than too big. At the same time we happen to be here because of popularity and that is a cause. As Lauri Vahtre referred to the view represented by the initiators of the draft contains the risk of destabilising society. Parliamentary democracy does not consider people dim-witted but admits that masses may be manipulated and an individual, not to mention individual groups, is never competent of the majority of things. There is always a danger of emotional assault and because of that we need the parliament as a filter even to decide the issue of officially taking a case for deliberation. I maintain 25,000 is a very weak filter. As parliament we have to assess and analyse if an issue is worth deliberation, that is why we have been called and constituted. Which way of thinking, that of the initiators or parliamentary representative democracy is more likely a preferred way of thinking on the path towards destructing democracy? I maintain there are problems in the parliamentary democracy but eventually it sooner prevents from that danger and, for sure, a populist way would be more certain for a dictatorship. Populism is political philosophy comparing authority against the people and allegedly speaks on behalf of people, with explicit aim of capturing power. We do possess such grimaces of democracy when an MP collects signatures on taxation issues which is not a 
referendum based topic according to the constitution, and he/she is not going to initiate a topic here in this hall as a draft bill. Such grimaces do exist but summing up the grimaces may be avoided and smoothed. The way of thinking by the initiators of the draft bill has been very characteristic of phenomena such as Chavez, Hitler, Peron, Mussolini, Larka, several movements by minorities. There are very many movements like that in Europe. There is much like that on the Internet. One of the outputs like that is lynch court. There is nothing else to add. The majority may be violent in regard to a certain minority to give a more drastic example. But we must not actually contrast people's initiative and representative democracy.

- Discourse of professional politics:

There can be no such a question whether people's initiative or not. It is our duty to develop further democracy, better take into account propositions arising from among people. Let us, though, be very careful with removing the filter, and if we need to loosen up the filter we will confess where we had made a mistake. The initiators of the draft should give specific examples for cases where they have diverted good and popular ideas for some reasons, and why they have done it. Our faction stays very careful about this draft and finds that 25,000 is insufficient. That is but a futile minority in society, and considering a destabilising influence of the extremes we do not support the draft in its present form. But we do admit the necessity to behave in a more democratic way here in the parliament. Thank you! (Jürgen Ligi, Reform Party).

\section{CONCLUSIONS}

The aim of this article is to consider why direct democracy has not been applied (in Estonia in particular) when problems concerning direct democracy have emerged. The article applies qualitative methodology, making use of shorthand records of the parliament. The article analyses these shorthand notes to find out what the attitude of the political parties represented in the parliament is towards direct democracy. The conclusion is reached that there is one direct democracy discourse split into two trends: one favoring direct democracy and one adverse to it. The situation in the parliament of Estonia addressed here occurred when the party in opposition wanted the constitution to be modified with a clause enabling popular initiative to be added. The analysis revealed that the predominant oppositional discourse prevailed throughout the period.

We can see here a strong clash of views: the proponents of direct democracy try to stress different aspects of "alienation of power"; for example, the parliamentary elections have been media-manipulated by certain interest groups. Alternatively, other speakers on the contrarian-side shared the views according to 
which direct democracy is unnecessary, even risky, and in any way a populist means to cope with the strain of governance ("The link between the referendum, people's initiative and the potential dismissal of the Riigikogu (the parliament) will cause social imbalance, not to say a risk of social disturbances. The risk for national security not only for the parliament and we should not let it happen.") The mechanisms of initiative remain unclear, while a collection of signatures may bring ungrounded hopes and issues not supported by the majority of the people. It does not reduce the alienation of the citizens and the state - quite the opposite. It is very important to develop civic society (e.g. to promote dialogues with voters and non-profit associations, such as the church) - but initiative does not help here specifically, because the people do not have expert-knowledge, otherwise urgently needed in contemporary politics.

It is characteristic of this debate as well as the following ones that there is no content relevant debate; instead both sides express their own views, and other delegates neither speak out nor support the speaker. No research has been conducted to clarify the issue, no experts were involved; however, the government's view was expressed and it was accepted. As there were no deliberations, no changes were made to the statement of the case. Rather the process was not very dynamic and ended in a mechanical voting; the predominant attitude was that "the parliament needn't be disturbed".

Between 2003 and 2008 a great deal changed in the political system: some parties disappeared and were replaced by others, and there were several coalitions in power as well as several prime minister; additionally, Estonia joined the European Union, and a large number of new laws and acts were adopted by the parliament. Analysing the shorthand notes showed that discourses on direct democracy remained for the entire period and deliberations, i.e. providing new arguments, did not change them. Political polarisation was of significance with proposals raised by the opposition being voted down. Some further conclusions on the basis of analysis include:

1. Within the eight years of discussion by the parliament about attitudes by the parties brought about no changes - the number of supporters, mostly restricted to Centre Party MPs, remained unchanged without going up or down. The number of opponents, including mostly representatives of the right-wing parties, i.e. Reform Party, Pro Patria Union and Res Publica, (the latter later united and it did not change the united parties attitude), remained firm;

2. Deliberations in the parliament did not substantially change anything. General relationships of power rested on the number of places a party received in the Riigikogu; during two compositions of the parliament the main idea of the 
discourse did not change much either; though the Estonian Greens emerging in 2007 added a dimension valuing direct democracy it did not change general relationships for power nor attitudes;

3. Reflections on the draft legislation and direct democracy were restricted to MPs "better understanding", or relying on the government, the Ministry of Justice or the Chancellor of Justice, on few occasions scientists were addressed (Juhan Kivirähk, Rein Toomla), but outside specialists were not involved and countries with first-hand experience of applying direct democracy were not addressed to learn about know-how; MPs were highly self-confident about the topic, the more so as the political powers passing to the parliament made legitimate a blind faith in their being infallible; not a single public opinion poll was carried out to find out what people actually thought of direct democracy and legalising the popular initiative;

4. The deliberations in the Great Hall of the Parliament in a prominent way distinguished a catalogue of the discourses on why direct democracy, in particular popular initiative, would not be necessary; on the contrary it could turn out to be dangerous. Hence a logical conflict: when people elect their representatives to the parliament, people may be trusted ("a competent choice"); if people were entitled to make direct decisions on matters concerning the state it would turn dangerous.

\section{BIBLIOGRAPHY}

1. Bourdieu, Pierre. Language and Symbolic Power. Cambridge: Harvard University Press, 1992.

2. Butler, David, and Austin Ranney. Referendums Around the World: The Growing Use of Direct Democracy. Washington: The American Enterprise Institute Press, 1994.

3. Estonian Human Development Report 2011. Baltic Way(s) of Human Development: Twenty Years On. Tallinn: Eesti Koostöö Kogu, 2011 // http://kogu.ee/public/eia2011/eia_eng_2011.pdf (accessed November 23, 2012).

4. LeDuc, Lawrence. The Politics of Direct Democracy. Referendums in Global Perspective. Toronto: University of Toronto Press, 2003.

5. Madise, Ülle, and Priit Vinkel. "Constitutionality of Remote Internet Voting: The Estonian Perspective." Juridica International VXIII (2011): 4-16.

6. Serdült, Uwe, and Yanina Welp. "Direct Democracy Upside Down." Taiwan Journal of Democracy 8:1 (2012): 69-92.

7. Setälä, Maija. "On the Problems of Responsibility and Accountability in Referendums." European Journal of Political Research 45 (2006): 699-721. 
8. Shenhav, Shaul R., Gideon Rahat, and Tamir Sheafer. "Testing the Language - Power Assumption of Critical Discourse Analysis: The Case of Israel's Legislative Discourse." Canadian Journal of Political Science / Revue canadienne de science politique 45:1 (2012): 207-222.

9. Shorthand Notes of the Riigikogu. Reading of the "Draft Act of the Amendment to the Constitution of the Republic of Estonia on Legalising the People's Initiative" (April 24, 2008) //

www. riigikogu.ee/ ?op=steno\&stcommand $=$ stenogramm\&date $=1209020700 \#$ pk2027 (accessed November 15, 2012).

10. Shorthand Notes of the Riigikogu. Reading of the "Draft Act of the Amendment to the Constitution of the Republic of Estonia on Legalising the People's Initiative" (March 22, 2005) // www.riigikogu.ee/?op=steno\&stcommand $=$ stenogramm\&date $=1111478400 \#$ pk2000011837 (accessed November 15, 2012).

11. Shorthand Notes of the Riigikogu. Reading of the "Draft Act of the Amendment to the Constitution of the Republic of Estonia on Legalising the People's Initiative" (October 7, 2003) // www.riigikogu.ee/ ?op=steno\&stcommand $=$ stenogramm\&date $=1065510000 \#$ pk2000010017 (accessed November 15, 2012).

12. Shorthand Notes of the Riigikogu. Reading of the "Draft Act of the Amendment to the Constitution of the Republic of Estonia on Legalising the People's Initiative" (October 24, 2006) // www.riigikogu.ee/?op=steno\&stcommand=stenogramm\&date $=1161673200 \#$ pk2000013387 (accessed November 15, 2012). 